UNIFESP

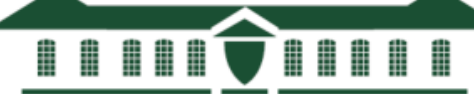

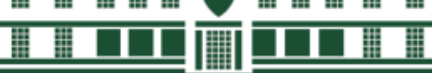

Role of Pep4 protein in Cryptococcus neoformans cell survival and virulence factors.

Gabrielle Felizardo ${ }^{\mathrm{a}}$, Renata C. Pascon ${ }^{\mathrm{a}}$ and Marcelo A. Vallim ${ }^{\mathrm{a}}$

a Universidade Federal de São Paulo (UNIFESP), Diadema, São Paulo, Brazil.

\title{
ABSTRACT
}

TFAPESP 圆CNPq

Cryptococcosis is a systemic mycosis of great clinical importance which mainly affects immune suppressed patients. Currently, two distinct species stand out as human pathogens, Cryptococcus neoformans and C. gattii. In Brazil, the species C. neoformans is the most prevalent and it is present in all geographic regions. This species, with worldwide distribution is responsible for high rates of morbidity and mortality. The treatment is limited to few drugs and some resistance to them has been reported elsewhere. Therefore, new research must be carried out to broad the knowledge regarding this yeast biology aiming at traits that could be new targets for antifungal drugs. Recently, our laboratory has characterized the APE4 gene of C. neoformans, which in S. cerevisiae, is involved in autophagy. The mutation of this gene resulted in an avirulent strain of $C$. neoformans in animal model. Therefore, this project aims to expand the knowledge of the autophagy process in this pathogenic yeast. The mechanism of autophagy is a conserved process, responsible for the cell's survival in the face of adverse conditions of nutritional deprivation (carbon and nitrogen source) and environmental stresses. We choose to evaluate the role of Pep4, a protease (Protease A), which in baker's yeast is responsible for maturation and activation of vacuolar hydrolases. These enzymes are involved in providing nitrogen under nutritional stress and maintaining homeostasis by recycling of cell proteins after exposure to oxidative stress. Pep4 protein acts in the autophagic vesicle. We assess the impact of C. neoformans PEP4 mutation has on the virulence factors (growth in different $\mathrm{pHs}$, high temperature $\left(37^{\circ} \mathrm{C}\right.$ ), production of phospholipase; melanin; and urease), as well as the response of yeast cell to stresses (saline, oxidative and nitrosative). Also the gene expression pattern associated with thermal, nitrosative stress and nutritional deprivation was evaluated. Our results shows that the pep4 mutant of $C$. neoformans produces significantly more capsule than the wild type strain $(\mathrm{KN} 99 \alpha)$ at $30^{\circ} \mathrm{C}$ and $37^{\circ} \mathrm{C}$, is sensitive to hydrogen peroxide and sodium nitrite under nutritional deprivation conditions. Moreover, the PEP4 gene expression is modulated by the combination of absence of carbon source, temperature and $\mathrm{NaNO}_{2}$. C. neoformans Pep4 protein is important for the yeast cell survival after exposure to sodium nitrite suggesting that in this pathogenic yeast, as in $S$. cerevisiae, this protein is involved in recycling damage proteins after nitrosative stress. (FAPESP 2015/04400-9, 2016/14542-8).

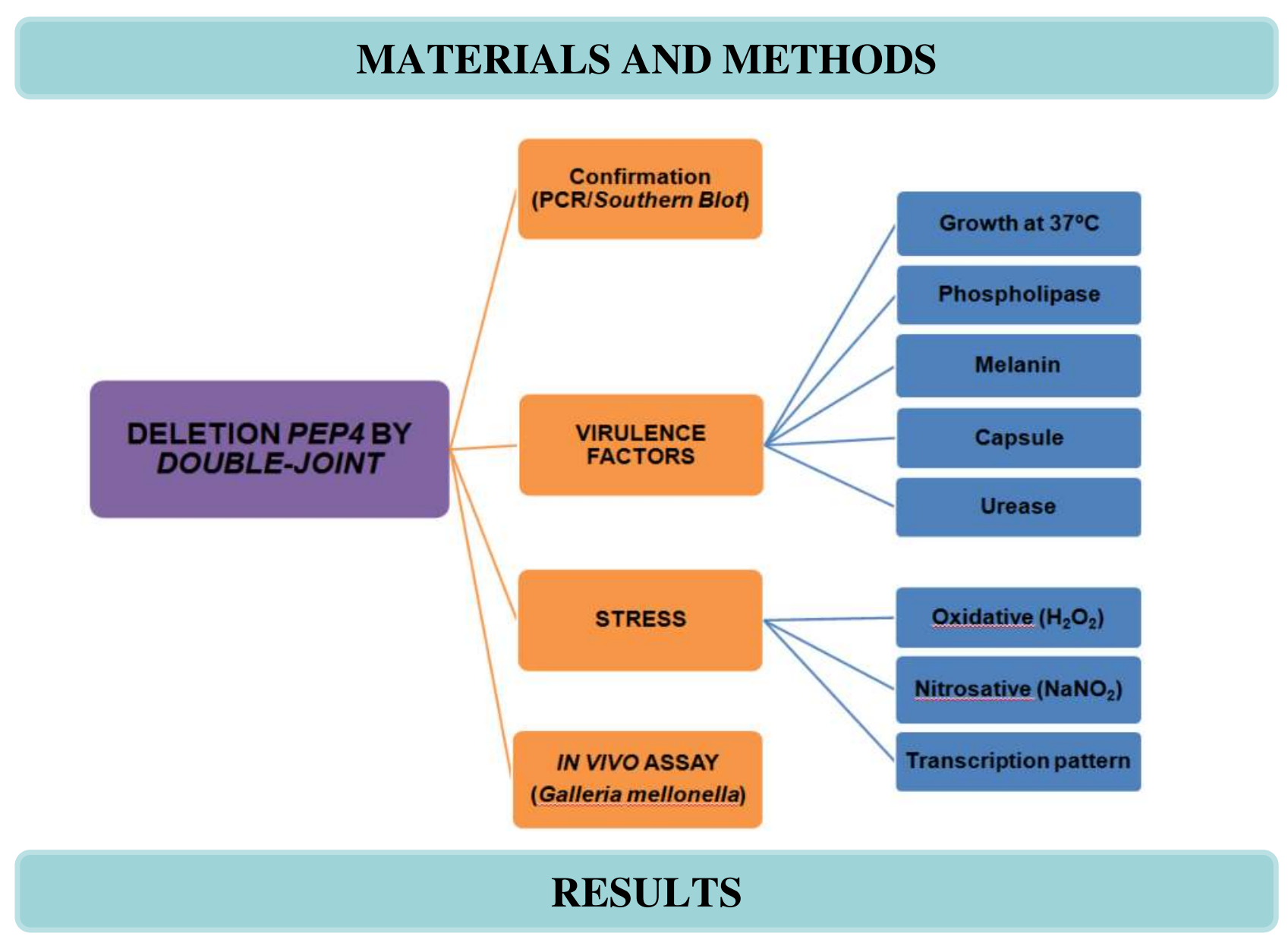

\section{Virulence factors}

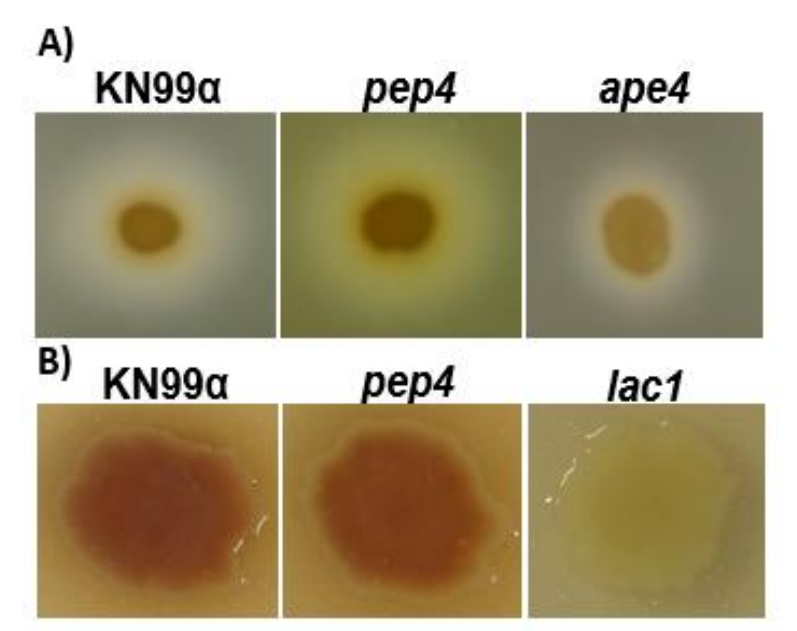

C) $\frac{30^{\circ} \mathrm{C}}{37^{\circ} \mathrm{C}}$

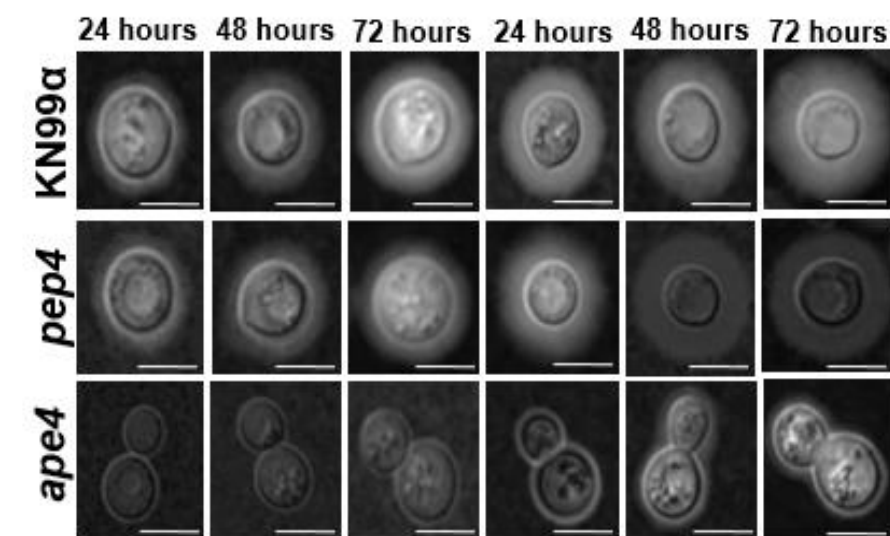

FIGURE 1: Virulence assays. A) Phospholipase production on yolk agar medium Incubation at $30^{\circ} \mathrm{C}$ for 96 hours. B) Melanin production on Niger seed agar medium. Incubation at $30^{\circ} \mathrm{C}$ for 96 hours. C) Capsule production in $\mathrm{CO}_{2}$-independent medium. Capsule production was evaluated with Indian-ink stain after 72 hours of incubation at $30^{\circ} \mathrm{C}$ and $37^{\circ} \mathrm{C}$. Scale bar represents $10 \mu \mathrm{m}$.

\section{Stress}
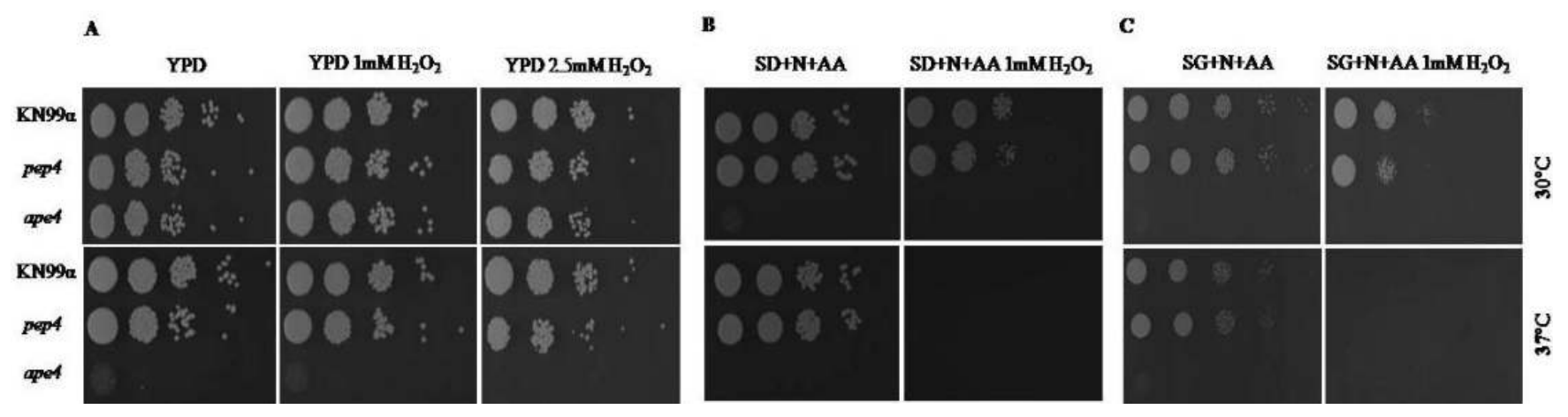

FIGURE 2. pep 4 mutant response to oxidative stress. The wild-type (KN99 $\alpha$ ) and pep4 strains were inoculated on (A) rich medium (YPD) supplemented or not with $1 \mathrm{mM}$ or $2.5 \mathrm{mM}$ of $\mathrm{H}_{2} \mathrm{O}_{2}$, (B) $\mathrm{SD}+\mathrm{N}+\mathrm{AA}$ with or without $1 \mathrm{mM}$ of $\mathrm{H}_{2} \mathrm{O}_{2}$ and C) $\mathrm{SG}+\mathrm{N}+\mathrm{AA}$ with or without $1 \mathrm{mM}$ of $\mathrm{H}_{2} \mathrm{O}_{2}$. $\mathrm{SD}+\mathrm{N}+\mathrm{AA}$ with or without $1 \mathrm{mM}$ of $\mathrm{H}_{2} \mathrm{O}_{2}$ and $\mathrm{C}$
Incubation occurred for 48 hours at $30^{\circ} \mathrm{C}$ and $37^{\circ} \mathrm{C}$.
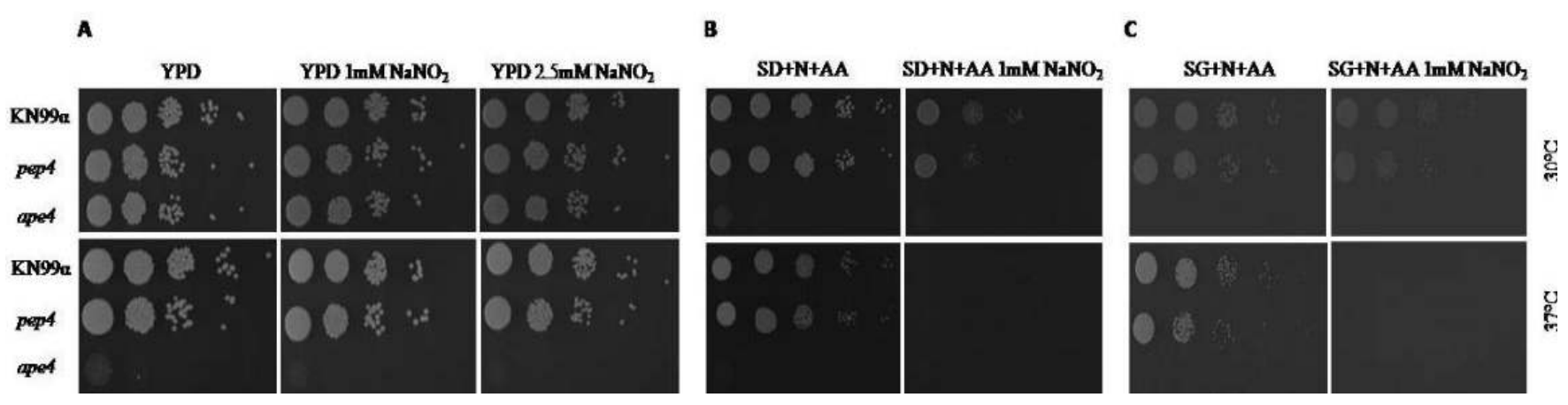

FIGURE 3. pep 4 mutant response to nitrosative stress. The wild-type (KN99 $\alpha$ ) and pep 4 strains were inoculated on (A) rich medium (YPD) supplemented or not with $1 \mathrm{mM}$ or $2.5 \mathrm{mM}$ of sodium nitrite $\left(\mathrm{NaNO}_{2}\right)$, (B) SD+N+AA supplemented or not with $1 \mathrm{mM}$ of $\mathrm{NaNO}_{2}$ and (C) with or without $1 \mathrm{mM}$ of $\mathrm{NaNO}_{2}$. Incubation occurred for 48 hours at $30^{\circ} \mathrm{C}$ and $37^{\circ} \mathrm{C}$.
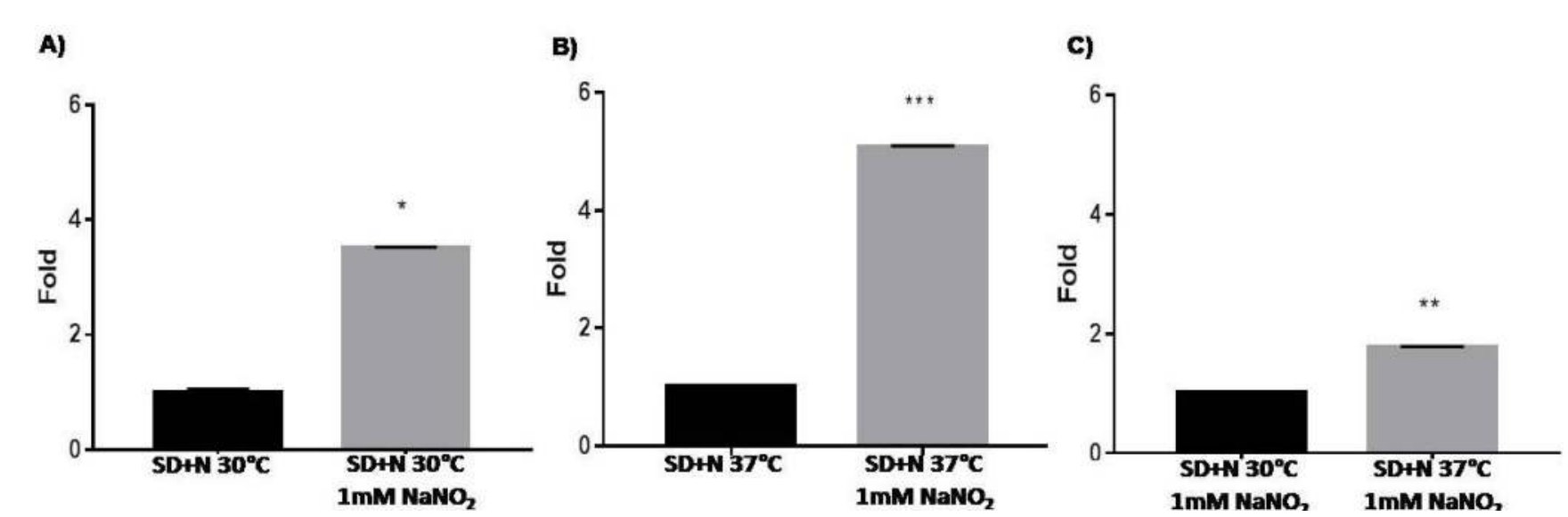

FIGURE 4. $P E P 4$ transcription pattern on (A) SD+N-AA in the absence versus presence of $1 \mathrm{mM}$ $\mathrm{NaNO}_{2}$ at $30^{\circ} \mathrm{C}$; (B) As in (A) but at $37^{\circ} \mathrm{C}$; (C) $\mathrm{SD}+\mathrm{N}-\mathrm{AA}$ supplemented with $1 \mathrm{mM} \mathrm{NaNO}$ at $30^{\circ} \mathrm{C}$ versus $37^{\circ} \mathrm{C}$. Significant differences were considered at $\mathrm{p}$ values $<0.05$ for the comparisons between the treatments.

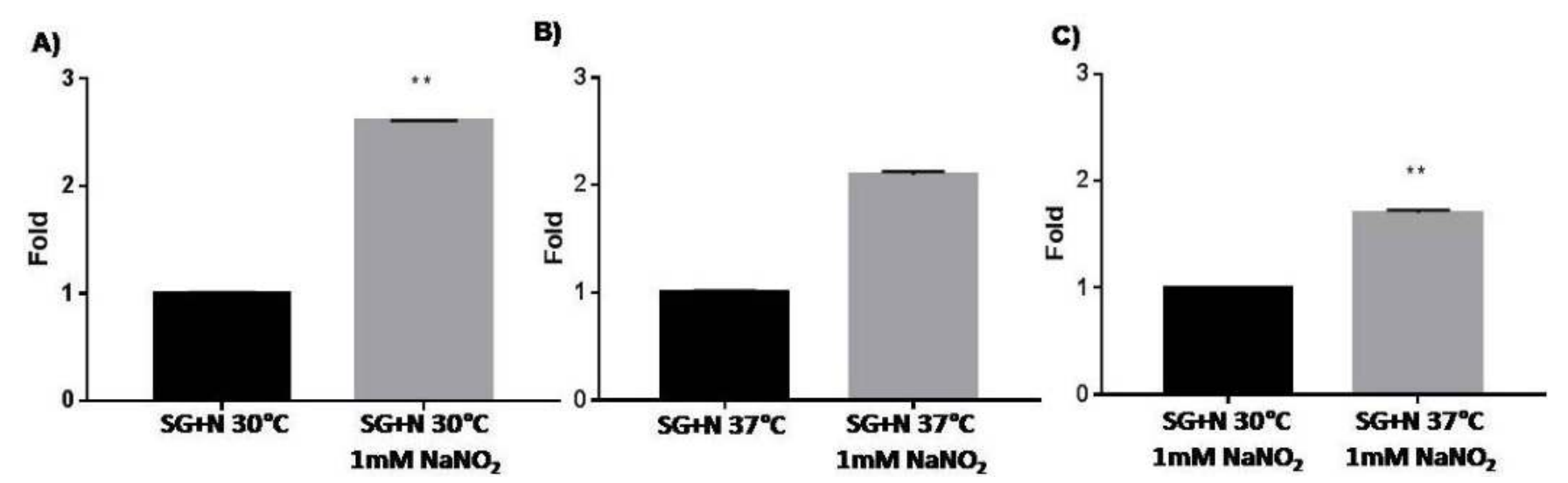

FIGURE 5. PEP4 transcription pattern on (A) $\mathrm{SG}+\mathrm{N}-\mathrm{AA}$ in the absence versus presence of $1 \mathrm{mM}$ $\mathrm{NaNO}_{2}$ at $30^{\circ} \mathrm{C}$. (B) As in (A) but at $37^{\circ} \mathrm{C}$; (C) $\mathrm{SG}+\mathrm{N}$-AA supplemented with $1 \mathrm{mM} \mathrm{NaNO}{ }_{2}$ at $30^{\circ} \mathrm{C}$ versus $37^{\circ} \mathrm{C}$. Significant differences were considered at $\mathrm{p}$ values $<0.05$ for the comparisons between the treatments.

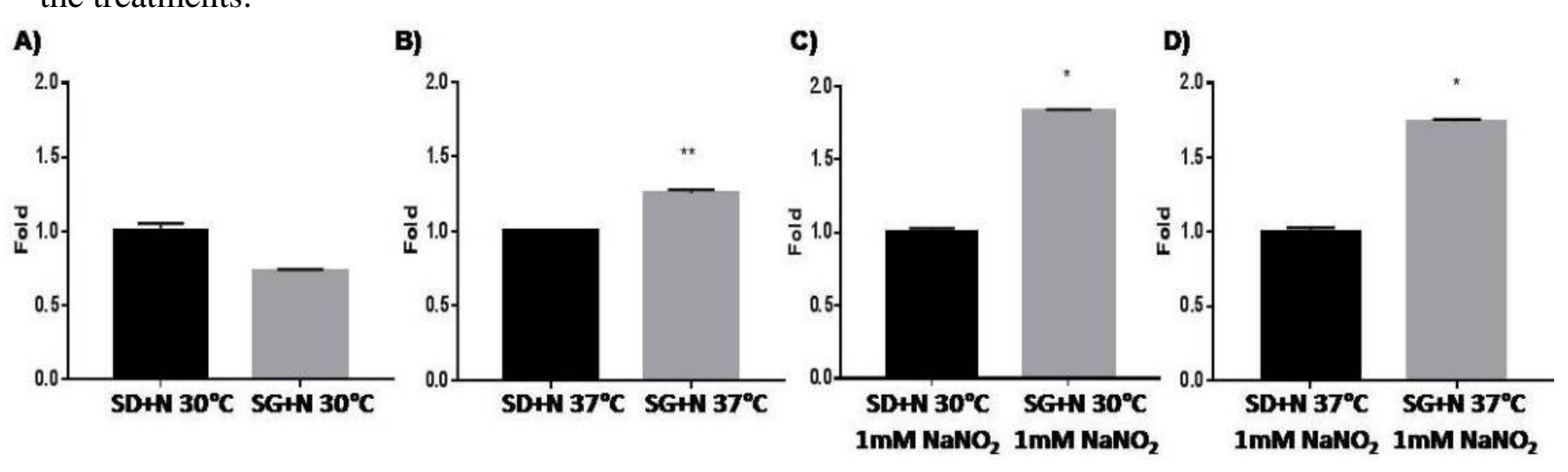

FIGURE 6. PEP4 transcription pattern on (A) $\mathrm{SD}+\mathrm{N}-\mathrm{AA}$ versus $\mathrm{SG}+\mathrm{N}-\mathrm{AA}$ at $30^{\circ} \mathrm{C}$, (B) as in (A) at $37^{\circ} \mathrm{C}$; (C) SD+N-AA versus SG+N-AA supplemented with $1 \mathrm{mM}$ of $\mathrm{NaNO}_{2}$ at $30^{\circ} \mathrm{C}$; (D) as in (C) at $37^{\circ} \mathrm{C}$. Significant differences were considered at $\mathrm{p}$ values $<0.05$ for the comparisons between the treatments.
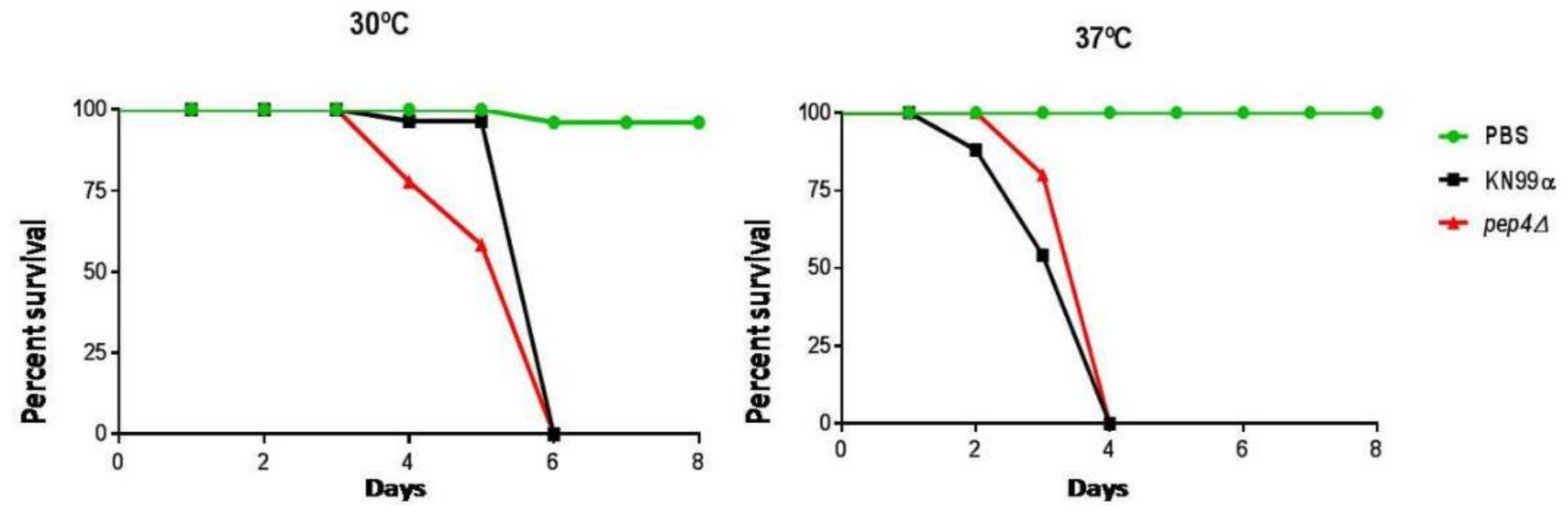

FIGURE 7. In vivo survival. Galleria mellonella larvae were inoculated with wild-type (KN99 $\alpha$ ) and pep4 mutant strains and incubated at $30^{\circ} \mathrm{C}(\mathrm{A})$ and $37^{\circ} \mathrm{C}(\mathrm{B})$ for 8 days. The PBS was used as negative control for in vivo assay.

\section{CONCLUSIONS}

This study shows that the pep4 mutant of C. neoformans produces significantly more capsule than the wild type strain $(\mathrm{KN} 99 \alpha)$ at $30^{\circ} \mathrm{C}$ and $37^{\circ} \mathrm{C}$, is sensitive to hydrogen peroxide and sodium nitrite under nutritional deprivation conditions.

Moreover, the PEP4 gene expression is modulated by the combination of absence of carbon source, temperature and $\mathrm{NaNO}_{2}$. 